\title{
Winogradskyella lutea sp. nov., isolated from seawater, and emended description of the genus Winogradskyella
}

Correspondence
Duck-Chul Oh
duckoh@jejunu.ac.kr

\author{
Byoung-Jun Yoon, ${ }^{1}$ Hoo-Dhon Byun, ${ }^{2}$ Ji-Young Kim, ${ }^{2}$ Dong-Heon Lee, ${ }^{3}$ \\ Hyung-Yeel Kahng ${ }^{4}$ and Duck-Chul Oh ${ }^{1,2}$
}

\author{
${ }^{1}$ The Research Institute for Basic Sciences, Jeju National University, Jeju 690-756, Republic of \\ Korea \\ ${ }^{2}$ Department of Biology, College of Natural Science, Jeju National University, Jeju 690-756, \\ Republic of Korea \\ ${ }^{3}$ Department of Chemical Engineering, Pohang University of Science and Technology, \\ Pohang 790-784, Republic of Korea \\ ${ }^{4}$ Department of Environmental Education, College of Education, Sunchon National University, \\ Sunchon 540-742, Republic of Korea
}

\begin{abstract}
A novel Gram-negative, orange-pigmented, rod-shaped, strictly aerobic, gliding, oxidase- and catalase-positive bacterial strain, $A 73^{\top}$, was isolated from seawater collected off Jeju, South Korea. 16S rRNA gene sequence similarity between $\mathrm{A} 3^{\top}$ and type strains of Winogradskyella species with validly published names ranged from 94.1 to $96.2 \%$. The dominant fatty acids of strain $A 73^{\top}$ were iso- $C_{15: 1} G(19.1 \%)$, iso- $C_{15: 0}(13.3 \%)$, iso- $C_{17: 0} 3-O H(10.0 \%)$ and iso- $\mathrm{C}_{15: 0} 3-\mathrm{OH}(7.2 \%)$. The DNA G $+\mathrm{C}$ content of strain $A 73^{\top}$ was $36.0 \mathrm{~mol} \%$ and its major respiratory quinone was $\mathrm{MK}-6$. On the basis of combined data from phenotypic and phylogenetic analyses, strain $\mathrm{A73}^{\top}$ represents a novel species of the genus Winogradskyella, for which the name Winogradskyella lutea sp. nov. is proposed. The type strain is $A 73^{\top}$ (=KCTC $23237^{\top}$ $=\mathrm{DSM} 22624^{\mathrm{T}}$ ). An emended description of the genus Winogradskyella is also provided.
\end{abstract}

The genus Winogradskyella was established by Nedashkovskaya et al. (2005). The genus belongs to the family Flavobacteriaceae and, at the time of writing, included nine species with validly published names from various marine habitats: Winogradskyella thalassocola (the type species), $W$. epiphytica and $W$. eximia were isolated from marine brown algae (Nedashkovskaya et al., 2005), W. poriferorum from a marine sponge (Lau et al., 2005), W. arenosi from marine sediments (Romanenko et al., 2009), W. echinorum from a sea urchin (Nedashkovskaya et al., 2009), W. rapida (Pinhassi et al., 2009) and W. pacifica (Kim \& Nedashkovskaya, 2010) from seawater and $W$. exilis from a starfish (Ivanova et al., 2010). The aim of the present study was to determine the exact taxonomic position of a novel bacterial isolate, strain $\mathrm{A} 73^{\mathrm{T}}$, by using a polyphasic characterization that included determination of phenotypic properties and a detailed phylogenetic investigation based on 16S rRNA gene sequences. The results of phylogenetic analysis based on $16 \mathrm{~S}$ rRNA gene sequences revealed that the novel isolate

The GenBank/EMBL/DDBJ accession number for the 16S rRNA gene sequence of strain $A 73^{\top}$ is FJ919968. belonged to the family Flavobacteriaceae and occupied a distinct lineage within the genus Winogradskyella.

Strain $\mathrm{A} 73^{\mathrm{T}}$ was isolated from a seawater sample that was collected off Jeju Island, Republic of Korea. The seawater sample was diluted with sterilized artificial seawater (Yoon et al., 2002), spread onto a plate of marine agar 2216 (MA; Difco) and incubated at $30{ }^{\circ} \mathrm{C}$. The isolate was routinely cultured on MA and stored as suspensions in $10 \%$ glycerol/marine broth 2216 (MB; Difco) at $-80{ }^{\circ} \mathrm{C}$. After the optimum growth temperature had been determined, cultures were maintained on $\mathrm{MA}$ or in $\mathrm{MB}$ at $30{ }^{\circ} \mathrm{C}$. For 16S rRNA gene amplification by PCR, DNA was extracted from a single colony by a boiling method (Englen \& Kelley, 2000). The crude extract served as DNA template for PCRs with Taq DNA polymerase (Bioneer) and primers $27 \mathrm{~F}$ and 1492R (Lane, 1991). PCR products were purified using the AccuPrep PCR purification kit (Bioneer). Sequencing of the amplified 16S rRNA gene fragment was performed with an Applied Biosystems automatic sequencer (ABI 3730XL) at Solgent Co. (Daejeon, Korea). The $16 \mathrm{~S}$ rRNA gene sequence (1341 bp) of strain $\mathrm{A} 73^{\mathrm{T}}$ was compared to those available in GenBank using the BLASTN program (Altschul et al., 1990) to determine an approximate phylogenetic 
affiliation, and the sequence was then aligned with those of closely related strains by using the CLUSTAL W software (Thompson et al., 1994). Sequence similarities were computed using the EzTaxon server (http://www.eztaxon. org/; Chun et al., 2007). Gaps at the 5' and 3' ends of the alignment were omitted from further analyses. Sequences were assembled using the BioEdit program (Hall, 2007). Phylogenetic trees were constructed with the neighbourjoining (Saitou \& Nei, 1987) and maximum-parsimony (Felsenstein, 1978) methods using the software package MEGA version 4.0 (Tamura et al., 2007) and with the maximum-likelihood method (Felsenstein, 1981) using PHYLIP version 3.67 (Felsenstein, 2007). Evolutionarydistance matrices were calculated according to the algorithm of the Jukes-Cantor model (Jukes \& Cantor, 1969) for the neighbour-joining method. The topologies of the resultant trees were evaluated using bootstrap analysis (Felsenstein, 1985) based on 1000 replicates. Phylogenetic analysis based on the nearly complete 16S rRNA gene sequence revealed that strain $A 73^{\mathrm{T}}$ was a member of the genus Winogradskyella (Fig. 1). The distinct phylogenetic position of strain $\mathrm{A} 73^{\mathrm{T}}$ was confirmed by the maximumlikelihood and maximum-parsimony trees (not shown). Its closest relatives were $W$. arenosi $\mathrm{R} 60^{\mathrm{T}}, W$. echinorum KMM $6211^{\mathrm{T}}$ and W. thalassocola KMM $3907^{\mathrm{T}}$, with 96.5 , 96.3 and $96.1 \%$ 16S rRNA gene sequence similarity, respectively.

The following tests were performed on strain $A 73^{\mathrm{T}}$ only. Cell morphology and the presence of flagella were assessed by light and transmission electron microscopy (JEM100; JEOL) using cells grown on MA at $30{ }^{\circ} \mathrm{C}$ for 4 days. The following tests were performed on strains $\mathrm{A} 73^{\mathrm{T}}, W$. arenosi JCM $15527^{\mathrm{T}}, W$. echinorum KCTC $22026^{\mathrm{T}}$ and $W$. thalassocola KCTC $12221^{\mathrm{T}}$ using the same culture conditions and methods. Gliding motility was assessed on $0.1 \times$ MA plates (containing $10 \%$ marine broth and $1 \%$ agar) (Bowman, 2000) and by the hanging drop method (Bernardet et al., 2002). The Gram reaction was assessed by using the bioMérieux Gram stain kit according to the manufacturer's instructions. Growth at 5, 10, 15, 20, 25, 30,

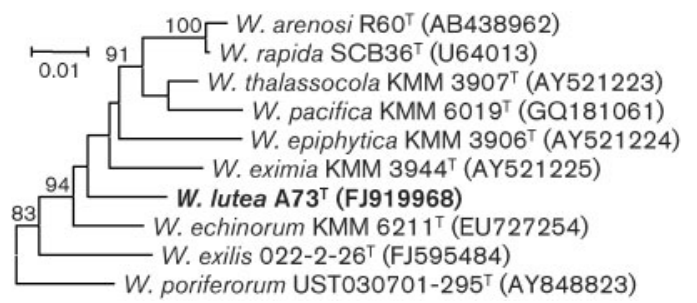

Fig. 1. Neighbour-joining phylogenetic tree based on 16S rRNA gene sequences, showing the relationships of strain $A 73^{\top}$ and related taxa. Bootstrap percentages (based on 1000 replicates) greater than $70 \%$ are shown at branching points. Bar, 0.01 changes per nucleotide position.
35, 40 and $45{ }^{\circ} \mathrm{C}$ was measured on MA, while growth at $\mathrm{pH} 3,4,5,5.5,6,6.5,7,7.5,8,8.5,9,9.5,10,10.5$ and 11 and tolerance of $1,1.5,2,2.5,3,3.5,4,5,6,7,8,9$ and $10 \%$ $(\mathrm{w} / \mathrm{v}) \mathrm{NaCl}$ was measured in $\mathrm{MB}$. The $\mathrm{pH}$ range for growth was determined by assessing changes in $\mathrm{OD}_{600}$ with time in MB. Tolerance of sea salts was determined on trypticase soy agar (TSA; Difco) supplemented with $0-12 \%(\mathrm{w} / \mathrm{v})$ sea salts (Sigma). Growth with $\mathrm{NaCl}$ as the sole salt was studied on TSA supplemented with $0-12 \%(\mathrm{w} / \mathrm{v}) \mathrm{NaCl}$. Anaerobic growth was assessed on MA incubated in a GasPak anaerobic system (BBL) for 15 days at $30{ }^{\circ} \mathrm{C}$. The presence of catalase activity was revealed by the production of oxygen bubbles by cells when mixed with $3 \%(\mathrm{v} / \mathrm{v}) \mathrm{H}_{2} \mathrm{O}_{2}$ on a glass slide. The presence of oxidase activity was determined by oxidation of $1 \%(\mathrm{w} / \mathrm{v}) \quad N, N, N^{\prime}, N^{\prime}$-tetramethyl-p-phenylenediamine solution. DNase activity was examined by using DNase test agar with methyl green (Difco) supplemented with $2 \%$ (w/v) sea salts (Sigma). Hydrolysis of casein, starch and Tweens 20, 40 and 80 was tested on MA, using the substrate concentrations given by Cowan \& Steel (1965). Hydrolysis of agar and CM-cellulose was investigated as described by Barrow \& Feltham (1993). Hydrolysis of aesculin, gelatin and urea and reduction of nitrate were investigated as described by Lányí (1987) using media supplemented with $2 \%(\mathrm{w} / \mathrm{v})$ sea salts. $\mathrm{H}_{2} \mathrm{~S}$ production was tested as described previously (Bruns et al., 2001). Other biochemical tests were performed using API 20NE and API 20E kits (bioMérieux) and enzyme activities were tested using an API ZYM kit (bioMérieux). API strips were inoculated with a heavy bacterial suspension (McFarland value of 0.5 ) in artificial seawater (Yoon et al., 2002) and used according to the manufacturer's instructions, except that tests were incubated at $30{ }^{\circ} \mathrm{C}$ for 4 days. Susceptibility to antibiotics was determined using the disc-diffusion method with commercial antibiotic-impregnated discs (BBL Becton Dickinson). After 4 days of incubation at $30{ }^{\circ} \mathrm{C}$ on MA, the results were interpreted according to the guidelines of the CLSI (2003). The main physiological, biochemical and morphological characteristics are given in the species description and in Table 1.

The presence of flexirubin-type pigments was investigated as described by Bernardet et al. (2002). Cellular fatty acid methyl esters of strain $\mathrm{A} 73^{\mathrm{T}}, W$. arenosi JCM $15527^{\mathrm{T}}, W$. echinorum KCTC $22026^{\mathrm{T}}$ and $W$. thalassocola KCTC $12221^{\mathrm{T}}$ were prepared from cultures grown on MA at $30{ }^{\circ} \mathrm{C}$ for 4 days and identified and quantified using the Sherlock Microbial Identification System (MIDI) according to the manufacturer's protocol. The dominant fatty acids of strain $\mathrm{A} 3^{\mathrm{T}}$ were iso- $\mathrm{C}_{15: 1} \mathrm{G}(19.1 \%)$, iso- $\mathrm{C}_{15: 0}$ $(13.3 \%)$, iso- $\mathrm{C}_{17: 0} 3-\mathrm{OH}(10.0 \%)$ and iso- $\mathrm{C}_{15: 0} 3-\mathrm{OH}$ $(7.2 \%)$. The detailed fatty acid profile of strain $A 73^{\mathrm{T}}$ is compared with those of closely related members of the genus Winogradskyella in Table 2. DNA was isolated from strain $\mathrm{A} 73^{\mathrm{T}}, W$. arenosi JCM $15527^{\mathrm{T}}$, W. echinorum KCTC $22026^{\mathrm{T}}$ and $W$. thalassocola KCTC $12221^{\mathrm{T}}$ by the method of Marmur (1961) and DNA G $+C$ content was determined 
Table 1. Differential characteristics of strain $A 73^{\top}$ and closely related type strains of the genus Winogradskyella

Strains: 1 , strain $\mathrm{A} 73^{\mathrm{T}} ; 2 . W$. arenosi $\mathrm{JCM} 15527^{\mathrm{T}} ; 3, W$. echinorum KCTC $22026^{\mathrm{T}} ; 4$, W. thalassocola KCTC $12221^{\mathrm{T}}$. Data were obtained in this study unless indicated. All strains were positive for the following: respiratory metabolism; gliding motility; oxidase, catalase and alkaline phosphatase activities; requirement for $\mathrm{Na}^{+}$ions for growth; utilization of D-glucose; hydrolysis of gelatin. All strains were negative for the following: nitrate reductase and urease activity; flexirubin pigments; indole and acetoin production; acid production from L-arabinose, inositol, melibiose, L-rhamnose, D-sorbitol and sucrose; utilization of L-arabinose, inositol, D-sorbitol and sucrose. All strains were susceptible to ampicillin, carbenicillin, chloramphenicol and oleandomycin and resistant to gentamicin, kanamycin, neomycin, polymyxin B and streptomycin (determined according to the criteria of the CLSI, 2003).

\begin{tabular}{|c|c|c|c|c|}
\hline Characteristic & 1 & 2 & 3 & 4 \\
\hline $\mathrm{H}_{2} \mathrm{~S}$ production & - & + & - & - \\
\hline \multicolumn{5}{|l|}{ Growth at/in: } \\
\hline $37^{\circ} \mathrm{C}$ & + & - & + & - \\
\hline $44{ }^{\circ} \mathrm{C}$ & - & - & $+(-)^{a_{\star}}$ & - \\
\hline $8 \% \mathrm{NaCl}$ & - & + & - & + \\
\hline \multicolumn{5}{|l|}{ Hydrolysis of: } \\
\hline Agar & - & - & - & + \\
\hline Casein & + & - & + & - \\
\hline Starch & + & + & - & - \\
\hline DNA & + & - & + & - \\
\hline CM-cellulose & + & - & - & - \\
\hline Tween 20 & - & + & - & - \\
\hline Tween 40 & - & + & - & + \\
\hline Tween 80 & + & + & - & - \\
\hline \multicolumn{5}{|l|}{ Acid formation from: } \\
\hline D-Glucose & + & + & - & + \\
\hline Maltose & - & + & - & + \\
\hline D-Mannitol & - & + & - & - \\
\hline \multicolumn{5}{|l|}{ Utilization of: } \\
\hline Citrate & + & - & - & - \\
\hline D-Mannose & - & + & + & + \\
\hline D-Mannitol & - & + & - & - \\
\hline \multicolumn{5}{|l|}{ Susceptibility to: } \\
\hline Benzylpenicillin & + & - & $+(-)^{a}$ & $+(-)^{b}$ \\
\hline Tetracycline & + & + & $+(-)^{a}$ & - \\
\hline $\begin{array}{l}\text { DNA G + C content } \\
(\mathrm{mol} \%)\end{array}$ & 36.0 & 34.5 & $33.5(33.6)^{a}$ & $32.0(34.6)^{b}$ \\
\hline
\end{tabular}

${ }^{*}$ Data in parentheses taken from: $a$, Nedashkovskaya et al. (2009); $b$, Nedashkovskaya et al. (2005).

by using the thermal denaturation method (Marmur \& Doty, 1962). The DNA $\mathrm{G}+\mathrm{C}$ contents of strain $\mathrm{A73}{ }^{\mathrm{T}}$, W. arenosi JCM $15527^{\mathrm{T}}, W$. echinorum KCTC $22026^{\mathrm{T}}$ and W. thalassocola KCTC $12221^{\mathrm{T}}$ were $36.0,34.5,33.5$ and $32.0 \mathrm{~mol} \%$, respectively. Isoprenoid quinones of strain $\mathrm{A}^{\mathrm{T}}$ only were analysed using an HPLC (ZQ 4000; Waters $)$ and a reversed-phase column $(300 \times 3.9 \mathrm{~mm}$,
Table 2. Cellular fatty acid contents of strain $A 73^{\top}$ and closely related type strains of Winogradskyella

Strains: 1 , strain $\mathrm{A} 73^{\mathrm{T}} ; 2$. W. arenosi $\mathrm{JCM} 15527^{\mathrm{T}} ; 3$, W. echinorum KCTC $22026^{\mathrm{T}} ; 4, W$. thalassocola KCTC $12221^{\mathrm{T}}$. Values are percentages of total fatty acids and were determined in this study. Fatty acids amounting to $<1 \%$ of the total fatty acids in all strains are not shown; -, not detected $(<1.0 \%)$.

\begin{tabular}{|c|c|c|c|c|}
\hline Fatty acid & 1 & 2 & 3 & 4 \\
\hline \multicolumn{5}{|l|}{ Saturated } \\
\hline $\mathrm{C}_{15: 0}$ & 6.4 & 3.0 & 2.2 & 2.0 \\
\hline $\mathrm{C}_{16: 0}$ & 1.3 & 1.3 & - & - \\
\hline \multicolumn{5}{|l|}{ Branched saturated } \\
\hline iso- $\mathrm{C}_{15: 0}$ & 13.3 & 18.1 & 15.2 & 14.5 \\
\hline iso- $\mathrm{C}_{16: 0}$ & - & 1.5 & 1.1 & 1.2 \\
\hline anteiso- $\mathrm{C}_{15: 0}$ & 3.4 & 11.9 & 12.4 & 11.4 \\
\hline \multicolumn{5}{|l|}{ Unsaturated } \\
\hline $\mathrm{C}_{15: 1} \omega 6 c$ & 1.5 & 1.0 & 1.8 & 1.2 \\
\hline \multicolumn{5}{|l|}{ Branched unsaturated } \\
\hline iso- $\mathrm{C}_{15: 1} \mathrm{G}$ & 19.1 & 15.0 & 14.9 & 14.1 \\
\hline anteiso- $\mathrm{C}_{15: 1} \mathrm{~A}$ & 1.5 & 3.0 & 2.8 & 3.0 \\
\hline iso- $\mathrm{C}_{16: 1} \mathrm{H}$ & 1.6 & 1.2 & 1.5 & - \\
\hline iso- $\mathrm{C}_{17: 1} \omega 9 c$ & 1.1 & 2.7 & 1.7 & 2.2 \\
\hline \multicolumn{5}{|l|}{ Hydroxy } \\
\hline $\mathrm{C}_{15: 0} 2-\mathrm{OH}$ & 1.6 & 1.9 & 2.3 & 3.4 \\
\hline $\mathrm{C}_{16: 0} 3-\mathrm{OH}$ & 1.6 & - & 1.1 & - \\
\hline $\mathrm{C}_{17: 0} 2-\mathrm{OH}$ & 2.3 & 2.8 & 2.6 & 2.9 \\
\hline iso- $\mathrm{C}_{15: 0} 3-\mathrm{OH}$ & 7.2 & 10.1 & 12.9 & 14.8 \\
\hline iso- $\mathrm{C}_{16: 0} 3-\mathrm{OH}$ & 6.2 & 6.0 & 8.5 & 8.0 \\
\hline iso- $\mathrm{C}_{17: 0} 3-\mathrm{OH}$ & 10.0 & 10.2 & 9.1 & 9.2 \\
\hline \multicolumn{5}{|l|}{ Summed feature } \\
\hline Summed feature $3^{*}$ & 5.0 & 5.3 & 5.7 & 5.5 \\
\hline
\end{tabular}

${ }^{*}$ Summed features are groups of two or three fatty acids that cannot be separated by the MIDI system. Summed feature 3 comprised iso$\mathrm{C}_{15: 0} 2-\mathrm{OH}$ and/or $\mathrm{C}_{16: 1} \omega 7 c$.

Nova-Pak C18; Waters) as described by Komagata \& Suzuki (1987). The major respiratory quinone of strain $\mathrm{A} 73^{\mathrm{T}}$ was MK-6.

Based on the results of the 16S rRNA gene-based phylogenetic analysis and the above-mentioned phenotypic features, we conclude that strain $\mathrm{A} 73^{\mathrm{T}}$ represents a novel species within the genus Winogradskyella, for which the name Winogradskyella lutea sp. nov. is proposed. As a consequence of newly reported characteristics, the description of the genus Winogradskyella Nedashkovskaya et al. 2005 is also emended.

\section{Emended description of genus Winogradskyella Nedashkovskaya et al. 2005}

The main characteristics are as given for the genus by Nedashkovskaya et al. (2005). In addition, colonies are yellow- or orange-pigmented. 


\section{Description of Winogradskyella lutea sp. nov.}

Winogradskyella lutea (lu'te.a. L. fem. adj. lutea orangecoloured).

Cells are $0.2-0.3 \mu \mathrm{m}$ wide and $2.0-3.5 \mu \mathrm{m}$ long. On MA, colonies are $1.0-1.5 \mathrm{~mm}$ in diameter, convex and circular/ slightly irregular and contain non-diffusible orange pigments. Devoid of flagella. Gliding motility is observed. Grows at $10.0-37.0{ }^{\circ} \mathrm{C}$ (optimum, $30.0-35.0{ }^{\circ} \mathrm{C}$ ) and at $\mathrm{pH}$ 6.0-11.0 (optimum, $\mathrm{pH}$ 7.0-8.0). Sodium ions are required for growth. Grows in $\mathrm{MB}$ supplemented with 1$3 \%(\mathrm{w} / \mathrm{v}) \mathrm{NaCl}$. Aesculin, Tween 80 , gelatin, starch, DNA, casein and CM-cellulose are hydrolysed, but Tweens 20 and 40, agar and urea are not. Acetoin, indole and $\mathrm{H}_{2} \mathrm{~S}$ are not produced. Nitrate is not reduced. Tryptophan deaminase, lysine decarboxylase and ornithine decarboxylase activities are absent. Acid is produced from D-glucose and citrate, but not from L-arabinose, inositol, melibiose, L-rhamnose, D-sorbitol, sucrose or amygdalin. D-Glucose is assimilated, but L-arabinose, D-mannose, D-mannitol, gluconate, adipic acid, malate, maltose, $\mathrm{N}$-acetylglucosamine, capric acid, trisodium citrate and phenylacetic acid are not. In API ZYM tests, alkaline phosphatase, esterase (C4), esterase lipase (C8), lipase (C14), leucine arylamidase, valine arylamidase, cystine arylamidase, trypsin, $\alpha$-chymotrypsin, acid phosphatase, naphthol-AS-BI-phosphohydrolase and $\beta$-glucosidase are present and $\alpha$-galactosidase, $\beta$-glucuronidase, $\alpha$-glucosidase, $N$-acetyl- $\beta$-glucosaminidase, $\alpha$ mannosidase and $\alpha$-fucosidase are absent. Susceptible to ( $\mu$ g per disc unless indicated) ampicillin (10), benzylpenicillin (10 U), carbenicillin (100), chloramphenicol (100), oleandomycin (15) and tetracycline (30); resistant to gentamicin (10), kanamycin (30), neomycin (30), polymyxin B (30) and streptomycin (10). The dominant fatty acids are iso- $\mathrm{C}_{15: 1} \mathrm{G}$, iso- $\mathrm{C}_{15: 0}$, iso- $\mathrm{C}_{17: 0} 3-\mathrm{OH}$ and iso$\mathrm{C}_{15: 0} 3-\mathrm{OH}$. The DNA G+C content of the type strain is $36.0 \mathrm{~mol} \%$.

The type strain, $\mathrm{A} 73^{\mathrm{T}}\left(=\right.$ KCTC $23237^{\mathrm{T}}=$ DSM $\left.22624^{\mathrm{T}}\right)$, was isolated from seawater collected off Jeju Island, Republic of Korea.

\section{Acknowledgements}

This work was partially supported by a research grant from Jeju National University in 2010.

\section{References}

Altschul, S. F., Gish, W., Miller, W., Myers, E. W. \& Lipman, D. J. (1990). Basic local alignment search tool. J Mol Biol 215, 403-410.

Barrow, G. I. \& Feltham, R. K. A. (editors) (1993). Cowan and Steel's Manual for the Identification of Medical Bacteria, 3rd edn. Cambridge: Cambridge University Press.

Bernardet, J. F., Nakagawa, Y. \& Holmes, B. (2002). Proposed minimal standards for describing new taxa of the family Flavobacteriaceae and emended description of the family. Int J Syst Evol Microbiol 52, 1049-1070.
Bowman, J. P. (2000). Description of Cellulophaga algicola sp. nov., isolated from the surfaces of Antarctic algae, and reclassification of Cytophaga uliginosa (ZoBell and Upham 1944) Reichenbach 1989 as Cellulophaga uliginosa comb. nov. Int J Syst Evol Microbiol 50, 18611868.

Bruns, A., Rohde, M. \& Berthe-Corti, L. (2001). Muricauda ruestringensis gen. nov., sp. nov., a facultatively anaerobic, appendaged bacterium from German North Sea intertidal sediment. Int J Syst Evol Microbiol 51, 1997-2006.

Chun, J., Lee, J.-H., Jung, Y., Kim, M., Kim, S., Kim, B. K. \& Lim, Y. W. (2007). EzTaxon: a web-based tool for the identification of prokaryotes based on $16 \mathrm{~S}$ ribosomal RNA gene sequences. Int J Syst Evol Microbiol 57, 2259-2261.

CLSI (2003). Performance standards for antimicrobial disk susceptibility tests, 8th edn. Approved Standard M2-A8. Wayne, PA: Clinical and Laboratory Standards Institute.

Cowan, S. T. \& Steel, K. J. (1965). Manual for the Identification of Medical Bacteria. London: Cambridge University Press.

Englen, M. D. \& Kelley, L. C. (2000). A rapid DNA isolation procedure for the identification of Campylobacter jejuni by the polymerase chain reaction. Lett Appl Microbiol 31, 421-426.

Felsenstein, J. (1978). Cases in which parsimony and compatibility methods will be positively misleading. Syst Zool 27, 401-410.

Felsenstein, J. (1981). Evolutionary trees from DNA sequences: a maximum likelihood approach. J Mol Evol 17, 368-376.

Felsenstein, J. (1985). Confidence limits on phylogenies: an approach using the bootstrap. Evolution 39, 783-791.

Felsenstein, J. (2007). PHYLIP (phylogeny inference package) version 3.67. Distributed by the author. Department of Genome Sciences, University of Washington, Seattle, USA.

Hall, T. (2007). BioEdit. Biological sequence alignment editor for Win95/ 98/NT/2K/XP. Carlsbad, CA: Ibis Biosciences.

Ivanova, E. P., Christen, R., Gorshkova, N. M., Zhukova, N. V., Kurilenko, V. V., Crawford, R. J. \& Mikhailov, V. V. (2010). Winogradskyella exilis sp. nov., isolated from the starfish Stellaster equestris, and emended description of the genus Winogradskyella. Int J Syst Evol Microbiol 60, 1577-1580.

Jukes, T. H. \& Cantor, C. R. (1969). Evolution of protein molecules. In Mammalian Protein Metabolism, vol. 3, pp. 21-132. Edited by H. N. Munro. New York: Academic Press.

Kim, S. B. \& Nedashkovskaya, O. I. (2010). Winogradskyella pacifica sp. nov., a marine bacterium of the family Flavobacteriaceae. Int J Syst Evol Microbiol 60, 1948-1951.

Komagata, K. \& Suzuki, K. (1987). Lipid and cell-wall analysis in bacterial systematics. Methods Microbiol 19, 161-207.

Lane, D. J. (1991). 16S/23S rRNA sequencing. In Nucleic Acid Techniques in Bacterial Systematics, pp. 115-175. Edited by E. Stackebrandt \& M. Goodfellow. Chichester: Wiley.

Lányí, B. (1987). Classical and rapid identification methods for medically important bacteria. Methods Microbiol 19, 1-67.

Lau, S. C. K., Tsoi, M. M. Y., Li, X., Plakhotnikova, I., Dobretsov, S., Lau, K. W. K., Wu, M., Wong, P.-K., Pawlik, J. R. \& Qian, P.-Y. (2005). Winogradskyella poriferorum sp. nov., a novel member of the family Flavobacteriaceae isolated from a sponge in the Bahamas. Int J Syst Evol Microbiol 55, 1589-1592.

Marmur, J. (1961). A procedure for the isolation of deoxyribonucleic acid from microorganisms. J Mol Biol 3, 208-218.

Marmur, J. \& Doty, P. (1962). Determination of the base composition of deoxyribonucleic acid from its thermal denaturation temperature. J Mol Biol 5, 109-118. 
Nedashkovskaya, O. I., Kim, S. B., Han, S. K., Snauwaert, C., Vancanneyt, M., Swings, J., Kim, K. O., Lysenko, A. M., Rohde, M. \& other authors (2005). Winogradskyella thalassocola gen. nov., sp. nov., Winogradskyella epiphytica sp. nov. and Winogradskyella eximia sp. nov., marine bacteria of the family Flavobacteriaceae. Int J Syst Evol Microbiol 55, 49-55.

Nedashkovskaya, O. I., Vancanneyt, M., Kim, S. B. \& Zhukova, N. V. (2009). Winogradskyella echinorum sp. nov., a marine bacterium of the family Flavobacteriaceae isolated from the sea urchin Strongylocentrotus intermedius. Int J Syst Evol Microbiol 59, 1465-1468.

Pinhassi, J., Nedashkovskaya, O. I., Hagström, Å. \& Vancanneyt, M. (2009). Winogradskyella rapida sp. nov., isolated from proteinenriched seawater. Int J Syst Evol Microbiol 59, 2180-2184.

Romanenko, L. A., Tanaka, N., Frolova, G. M. \& Mikhailov, V. V. (2009). Winogradskyella arenosi sp. nov., a member of the family
Flavobacteriaceae isolated from marine sediments from the Sea of Japan. Int J Syst Evol Microbiol 59, 1443-1446.

Saitou, N. \& Nei, M. (1987). The neighbor-joining method: a new method for reconstructing phylogenetic trees. Mol Biol Evol 4, 406-425.

Tamura, K., Dudley, J., Nei, M. \& Kumar, S. (2007). MEGA4: molecular evolutionary genetics analysis (MEGA) software version 4.0. Mol Biol Evol 24, 1596-1599.

Thompson, J. D., Higgins, D. G. \& Gibson, T. J. (1994). CLUSTAL W: improving the sensitivity of progressive multiple sequence alignment through sequence weighting, position-specific gap penalties and weight matrix choice. Nucleic Acids Res 22, 4673-4680.

Yoon, J. H., Lee, K. C., Kho, Y. H., Kang, K. H., Kim, C. J. \& Park, Y. H. (2002). Halomonas alimentaria sp. nov., isolated from jeotgal, a traditional Korean fermented seafood. Int J Syst Evol Microbiol 52, 123-130. 